\section{Kaupungin muuttuvat luonnot}

\author{
Ranja Hautamäki \& Julia Donner
}

\section{Luonto kaupungissa ja kaupunki luon- nossa}

Kaupunkisuunnittelun luonto on jatkuvasti muuntuva käsite, joka ilmenee suunnittelijoiden pyrkimyksissä määritellä hyvää asuinympäristöä ja sen ihanteellista luontoa. Luonto näyttäytyy samaan aikaan sekä suunnittelua ohjaavina mielikuvina että suunnittelun, rakentamisen ja hoidon kohteena. Kaupunkiluontoon voidaan liitää esteettisiä mutta myös moraalisia, hygieenisiä ja sosiaalisia tavoitteita, jotka saavat muotonsa asuinalueiden asemakaavoissa, viheralueverkostossa ja yksittäisten puistojen ja pihojen suunnittelussa. ${ }^{1}$ Luontokäsitykset ovat muuttuneet kaupungistumisen, teollistumisen ja yhteiskunnallisten tilanteiden sekä tieteellisen kehityksen mukaan. Ne ovat kulttuurisesti ja historiallisesti rakentuneita ja Raymond Williamsia siteeraten "luontoon projisoituja käsityksiä inmisistä"2. Käsitykset kertovat, millaista luontoa on arvostettu ja miten luonto on eri aikoina valjastettu yhteis- kunnan palvelukseen. Kaupunkisuunnittelussa luontoon esitetty milloin rakentamattomana luontona tai hoidettuna puistoluontona, milloin rationaalisena kaupunkivihreänä. Tarkastelemme artikkelissamme sodanjälkeisen Suomen kaupunkisuunnittelun erilaisia luontokäsityksiä erityisesti maisemasuunnittelun näkökulmasta. Ankkuroidumme kaupunkisuunnittelun keskeisiin paradigmoihin 1950-1970-luvulla: puutarha-, metsä- jakompaktikaupunkiin. Puutarhakaupunki-ideologian malliyhdyskunnassa Tapiolassa luonto ja maisema-arkkitehtuuri muodostivat modernin kaupunkimaiseman. Tapiolan jälkeisessä metsäkaupunkiajattelussa korostui pyrkimys alkuperäisen luonnon säilyttämiseen rakennetun puistomaiseman sijaan. 1960-luvulta lähtien kompaktikaupunkien tehokkaissa ruutukaavoissa luonnonläheisyyden korvasivat rakennettu kaupunkivihreä ja sosiaalisten kontaktien verkostot. Luonto kytkeytyy näiden kaupunki-ihanteiden esteettisiin tavoitteisiin ja myös sosiaalisiin. pyrkimyksiin sekä hyvinvointiyhteiskunnan rakentamiseen. Maisema-arkkitehtuurista tuli näiden pyrkimysten tärkeä välittäjä, ulkotilojen arkkitehtonisen ilmeen luojana ja kaupunkirakenteen ekologisten lähtökohtien määrittelijänä.

Artikkelimme keskiössä on maisema-arkkitehtuuri sotienjälkeisessä asuinaluerakentamisessa. Pohdimme artikkelissamme, mitä merkityksiä kaupunkisuunnittelijat ja maisema-arkkitehdit antoivat luonnolle ja miten maisema-arkkitehtuuria ja siinä tavoiteltua hyvää asuinympäristöä ja ihanteellista luontoa tuotettiin? Miten ja miksi suhde luontoon muuttui siirryttäessä puutarhakaupungista metsäkaupunkiin ja edelleen kompaktiin kaupunkiin? Pyrimme osoittamaan kaupunkisuunnittelun luontokäsitysten eroja, mutta myös samankaltaisuuksia. Tuomme esille, että puutarha-, metsä- ja kompaktikaupungin erilaiset luontorepresentaatiot eivät ole vastakkaisia ja toisensa poissulkevia vaan toisiaan täydentäviä. 
Esimerkkikohteina tarkastelemme suunnitteluparadigman muutosta ilmentävää kolmea pääkaupunkiseudulla sijaitsevaa asuinaluetta: Espoon Tapiolaa ja Helsingissä nykyisin Keski-Vuosaarena tunnettua Vuosaarta sekä Itä-Pasilaa. Havainnollistamme kohteita kolmen maisemaarkkitehdin suunnittelutöiden avulla: Tapiolassa toimineen Jussi Jänneksen, Keski-Vuosaarta suunnitelleen Katri Luostarisen ja Itä-Pasilasta vastanneen Leena lisakkilan. Tapiola on puutarhakaupunki-ideologian tunnetuin ja kunnianhimoisin toteutus, jonka kaavoitus alkoi 1940-luvulla. Asemakaavoituksen lähtökohtana oli maisemarakenne, ja näyttävät puistot sekä luonnonläheiset asuinalueet olivat erottamaton osa kaupunginosan identiteettiä. Keski-Vuosaaren edustama metsäkaupunki taas kuvaa 1950-luvulta lähtien rakennettuja väljiä ja luonnonläheisiä asuinalueita, jotka jatkoivat puutarhakaupungin pyrkimyksiä, korostaen kuitenkin voimakkaammin rakentamattoman luonnon merkitystä. Itä-Pasilan edustama kompaktikaupunki viittaa 1960-luvun lopulta alkaneeseen paradigman muutokseen ja teollisen rakentamisen kauteen, jossa korostuivat tehokas ruutukaava, sosiaaliset verkostot ja rakennettu kaupunkivihreä. Puutarha- ja metsäkaupunki sekä kompaktikaupunki pal- velivat kaikki omalla tavallaan hyvinvointiyhteiskunnan rakentamista, mutta niiden suunnittelukeinot ja suhde luontoon erosivat huomattavasti toisistaan.

Artikkelimme ensisijaisena lähdeaineistona ovat esimerkkialueiden maisemasuunnittelua koskevat dokumentit sekä aineistoa täydentävät maisema-arkkitehtien kirjoitukset, jotka avaavat heidän suunnitteluperiaatteitaan. Kirjoitukset esimerkiksi puutarha-alan lehdissä ovat olennaisia, sillä ${ }^{2}$ suunnitelmiin ei tuona aikana liittynyt varsinaisia selostuksia. Maisemasuunnittelua tarkastellaan kahdella tasolla: sekä arkkitehtuurin traditioon kiinnittyvänä, esteettisyyttä korostavana alana että normatiivista kaupunkisuunnittelua ilmentävänä alana, joka pyrkii määrittelemään hyvää kaupunkiympäristöä ja luomaan edellytyksiä hyvälle kaupunkielämälle. $^{3}$

Maisemasuunnittelu kytkeytyy tiiviisti asemakaavoitukseen ja rakennetun ympäristön suunnitteluun kulkien joko sen rinnalla tai seuraten sen asettamia askelmerkkejä. Esimerkkikohteiden suunnitelma-aineistoa ja maisema-arkkitehtien kirjoituksia täydentävät sen vuoksi myös arkkitehtien kirjoitukset, jotka taustoittavat aikakauden suunnitteluihanteita. Arkkitehtuurin ja maisema-arkkitehtuurin monisyinen kytkeytyminen ja kes- kinäiset vaikutteet ovat tärkeä lähtökohta lähiötutkimukselle. Oma artikkelimme keskittyy nimenomaan maisema-arkkitehtuuriin ja korostaa sen itsenäistä roolia kaupunkisuunnittelussa, mikä ansaitsee mielestämme huomiota. Koska tavoitteenamme on kokonaiskuvan luominen eri suunnitteluajanjaksojen pyrkimyksistä, emme käsittele yksityiskohtaisesti esimerkkikohteiden moniulotteisia ja pitkiä kaavoitusprosesseja. Arkkitehtuurin ja maisema-arkkitehtuurin suhteen tarkempi analyysi olisi kuitenkin kiinnostava ja tarpeellinen tutkimusaihe, joka täydentäisi kuvaa suomalaisesta lähiöstä.

Artikkeli painottuu kaupunkityyppien maisema-arkkitehtuuriin yleisesti, ei niinkään näiden kolmen suunnittelijan tuotannon analyysiin. Aikalaiskeskustelu keskittyy kotimaahan ja kansainvälistä maisema-arkkitehtuurikeskustelua käsitellään vain yleispiirteisesti. Jänneksen, Luostarisen ja lisakkilan suunnittelun kansainväliset vaikuttimet ovat tutkimusaiheena kartoittamatta, samoin kuin sodanjälkeiseen maisema-arkkitehtuuriin heijastunut yleinen kansainvälinen keskustelu. Kansainväliset vaikutteet suomalaiseen moderniin maisema-arkkitehtuuriin olisi kuitenkin hyvin kiinnostava ja tärkeä jatkotutkimuksen aihe.

Tapiolan esimerkkikohteen aineistona ovat erityisesti puutarha-arkkitehti Jussi Jännek- 
sen suunnitelmat, joita maisema-arkkitehti Ria Ruokonen on kartoittanut diplomityössään (1992). Tapiolan suunnittelua on lisäksi käsitelty laajasti erilaisissa tutkimuksissa ja julkaisuissa. ${ }^{4}$ Jännes itse kirjoitti kahdessa 1960-luvulla julkaistussa artikkelissa Tapiolan suunnittelusta, ja nämä artikkelit on otettu huomioon Tapiolan tarkastelussa. ${ }^{5}$ Tausta-aineistona on lisäksi Puutarhalehdessä käyty keskustelu erityisesti kasvien käytöstä Tapiolan maisemasuunnittelussa. ${ }^{6}$ KeskiVuosaaren aineistona on maisema-arkkitehti Katri Luostarisen (1915-1991) parikymmentä suunnitelmaa vuosilta 1964-1969 Arkkitehtuurimuseon kokoelmassa. Aineiston tarkastelua ovat syventäneet Luostarisen kirjoittamat kaksi kirjaa: Puutarha ja maisema (1951) ja Viihtyisä piha (1966), joissa hän käsitteli maisemasuunnittelua laajoista kokonaisuuksista pieniin puutarhan yksityiskohtiin. Näistä erityisesti ensimmäinen teos avaa Luostarisen suunnitteluperiaatteita. Aluetta on lisäksi selvitetty aiemmin kahdessa perusteellisessa inventointiraportissa. ${ }^{7}$ Itä-Pasilan lähdeaineistona on maisema-arkkitehti Leena lisakkilan (1927-) kattava suunnitelma-aineisto Arkkitehtuurimuseossa. Itä-Pasilaa ei ole inventoitu ja aluetta koskeva lähdekirjallisuus koskee pääosin kaupunkirakentamista. lisakkilan ajatuksia valaisevat lisäksi hänen teoksensa Piha vihreäksi - neljä suunnitteluesimerkkiä (1985) ja erityisesti Maisema-arkkitehti ajan virrassa (2000), johon hän kokosi suunnittelutöitään 1960-1990-luvuilta.

Suomessa sodanjälkeistä asuinaluesuunnittelua ja lähiörakentamista on tutkittu kaupunkisuunnittelun ja arkkitehtuurin näkökulmasta, mutta suhde luontoon ja erityisesti asuinalueiden viheralueita suunnitelleiden maisema-arkkitehtien työ on jäänyt arkkitehtuurin varjoon. Tutkimuksemme kytkeytyy aiempaan suomalaista lähiörakentamista käsittelevää monipuoliseen tutkimukseen, jota pyrimme täydentämään keskittymällä nimenomaan maisemaarkkitehtuuriin. Tärkeänä innoittajana on ollut maantieteilijä Virpi Hirvensalon väitös (2006), joka käsittelee lähiöiden luontosuhdetta. Lähiöitä on tarkasteltu monipuolisesti erityisesti taidehistorian tutkimuksissa, jotka luovat työllemme tärkeän kontekstin. Riitta Hurme on kuvannut väitöskirjassaan (1991) suomalaisen lähiön kehitystä Tapiolan puutarhakaupungista Pihlajamäen metsäkaupunkiin. Ulla Salmela (2004) on käsitellyt Otto-livari Meurmanin työtä kaupunkisuunnittelijana 1910-1930-luvuilla ja hänen käsitystään hyvästä kaupungista, mikä heijastui myöhemmin lähiörakentamisen aikaan. Juhana Lahden väitöskirja (2006) kuvaa puolestaan seuraavia vuosikymmeniä ja Aarne Ervin työtä kaupunkisuunnittelijana 1940-1960- luvuilla, joita leimasi kaavoitusta ohjaavan lainsäädännön ja kaavoitusorganisaatioiden uudistuminen. Sama ajanjakso on tarkastelussa myös Timo Tuomen kaupunkikeskustojen muutosta koskevassa väitöskirjassa (2005). 1960-luvun rakennemuutos ja sen käynnistämä tehokas lähiörakentaminen ja kompaktin kivikaupungin tavoittelu tulevat perinpohjaisesti käsitellyiksi Johanna Hankosen arkkitehtuurin väitöskirjassa (1994). Taidehistorioitsija Kirsi Saarikangas on tarkastellut laaja-alaisesti suomalaisen asumisen kehitystä asuntosuunnittelusta asuinalueiden suunnitteluun ja tuonut esille myös rakennetun ympäristön ja luonnon suhdetta. Vuonna 2016 ilmestyneessä maisema-arkkitehtuurin kokoomateoksessa Unelma paremmasta maailmasta käsitellään ensimmäisen kerran laajemmin asuinalueiden maisemasuunnittelua. ${ }^{8}$

\section{Luonto kaupunkisuunnittelussa}

Kaupunkiluonto on käsitteenä monitahoinen ja sisäisesti ristiriitainen, sillä kaupunki ja luonto vaikuttavat yleisesti toisensa poissulkevilta. ${ }^{9}$ Käsitteeseen sisältyy myös arvolatausta: kaupungissa olevaa luontoa on pi- 
detty epäluontona ja kaupungin ulkopuolista luontoa aitona luontona. Petteri Kummala (2016) tuo esille väitöskirjassaan, että luonnollisuuteen tai alkuperäisyyteen palautuvat lähestymistavat ovat kaupunkiluonnon arvioinnissa väistämättä puutteellisia. ${ }^{10}$ Hän ehdottaa kaupunkiluonnon tarkastelun lähestymistavaksi Bruno Latourin hybridin käsitettä, jossa yhdistyvät kulttuurisen ja luonnollisen luonnon moninaiset yhdistelmät.11 Anne Whiston Spirn kuvaa kirjassaan The Granite Garden (1984) kaupunkia urbaanina ekosysteeminä, joka ei ole kokonaan luonnollinen eikä myöskään täysin rakennettu tai luonnoton. Sen sijaan kaupunkiluonnossa näkyy transformaatio, muutosprosessi, jossa luontoa valjastetaan ihmiskunnan tarpeisiin. ${ }^{12}$ Kaupunkiluonnossa on siten aina luettavissa inmisen vaikutus - suunnittelijan tai poliittisen päättäjän kädenjälki. ${ }^{13}$

Myös Stephanie Ross (2006) korostaa kaupunkiluonnon moninaisuutta ja esittää ymmärtämisen avaimiksi luonnon eri mittakaavoja ja luonnollisuuden asteita. ${ }^{14}$ Hänen mukaansa luonto näyttäytyy makro- ja mikrotasolla ja ulottuu laaja-alaisista maisemista ja sääilmiöistä pienikokoisiin kohteisiin, kuten yksittäiseen kasviin tai kastepisaraan. Ross on laatinut kaupunkiluonnon asteittaisuuden luokittelun ja jakanut sen keskeytettyyn, muutettuun, rakennettuun ja keinotekoiseen luontoon. Näistä ensimmäinen luokka viittaa ennallistettuihin luontokohteisiin ja toinen luokka taas kohteisiin, joissa luonnon prosesseja ja sisältöjä on muunneltu. Kolmas kategoria kuvaa kokonaan uudelleen rakennettua luontoa ja neljäs keinotekoista simuloitua luontoa. Rossin luokittelu tuo kiinnostavasti esille kaupunkiluonnon moninaisuutta, mutta korostaa "puhdasta" luontoa"15 eikä ota riittävästi huomioon maisema-arkkitehtuurin tuottamaa uutta luontoa.

Kaupunkiluonnon monitahoisuuteen liittyy myös sen toisaalta käsitteellinen ja toisaalta materiaalinen luonne. Luonnolla voidaan viitata sekä paikkaan ja sen fyysisiin luontotekijöihin että käsitteellisesti kulttuurin ulkopuolella olevaan "toiseuteen". ${ }^{16}$ Matthew Gandy (2002) määrittelee kaupunkiluonnon vuoropuheluna kahden ulottuvuuden välillä: luonnon biofyysisen olemuksen ja kulttuurisesti rakentuneen kuvitteellisen luonnon välillä. ${ }^{17}$ Omassa työssämme tarkastelemme käsitteen molempia ulottuvuuksia: sekä luonnon käsitteellistä, kulttuurista tulkintaa että sen materiaalista rakentumista maisema-arkki- tehtuurissa. Rajaamme kaupunkiluonnon tarkastelun maisemasuunnittelun tuottamaan kaupunkivihreään tietoisina siitä, että monet edellä mainitut luonnon ulottuvuudet jäävät siten ulkopuolelle. Maisema-arkkitehtuuri sekä heijastaa että konkreettisesti rakentaa ihmisen ja luonnon välistä suhdetta. Poikkitieteellisenä professiona se syntetisoi luonnontieteellistä, humanistista ja teknistä tietoa sekä taiteellista ilmaisua tilalliseen muotoon ja pyrkii luomaan sekä ekologisesti että sosiaalisesti kestävää ja toimivaa ympäristöä. ${ }^{18}$

Luonto ja kaupunki muodostavat keskeisen käsiteparin ja jännitteen maankäytön suunnittelussa. Akateeminen keskustelu on korostanut yhteiskunnan ja luonnon moninaista ja monitasoista kietoutumista toisiinsa. Kaupungin ja luonnon suhdetta on tutkittu monipuolisesti, mutta suhteen materiaalinen ja tilallinen tarkastelu on jäänyt vähemmälle huomiolle. ${ }^{19}$ Modernismille on ollut tyypillistä dualistinen ajattelu, jossa kaupunki ja luonto erotetaan toisistaan ja asetetaan toistensa vastakohdiksi. Dualismi ei ilmene ainoastaan teoreettisella ja käsitteellisellä tasolla vaan se on toteutunut myös kaupunkisuunnittelussa ja sen tilallisissa ratkaisuis- 
sa. ${ }^{20}$ Valsson (1999) on erottanut erilaisia jaksoja luonnon ja kaupungin jännitteisessä suhteessa. Kehitys ei ole kulkenut suoraviivaisesti vaan aaltoillen, ennemminkin reaktioina ja vastareaktioina. Vaihtuvat ihanteet tavoiteltavasta maankäytön tehokkuudesta ja arkkitehtonisen muodonannon geometrisyydestä tai orgaanisuudesta ovat määrittäneet kehityksen kulkua. Valssonin mukaan moderni kaupunkisuunnittelu voidaan karkeasti jakaa kolmeen vaiheeseen: yhtenäisyyden aikaan, vieraantuneisuuden aikaan ja uuden yhtenäisyyden kauteen. ${ }^{21}$ Suomen 1940-60-lukujen puutarha- ja metsäkaupunki ilmentää ensimmäistä vaihetta, jossa rakentaminen sijoitettiin huolellisesti maisemaan maaston topografiaa ja luonnonelementtejä säästäen. 1960-luvun lopulta alkanut kompaktikaupunkivaihe puolestaan edustaa Valssonin mukaan vieraantuneisuutta, jossa luonnontilaisen luonnon korvasi rakennettu kaupunkivihreä ja aito luonto eristettiin kaupungista. ${ }^{22}$ Vaikka Valssonin luoma malli on vahvasti yksinkertaistettu, se onnistuu kuitenkin tavoittamaan jotakin hyvin olennaista kaupunkisuunnittelun narratiivista.

Puutarha- ja metsäkaupungin sekä kompaktikaupungin luontokäsityksissä on jatku- moita mutta myös kiinnostavia vastakohtia. Erityisesti kompaktikaupunki on useimmiten esitetty puutarha- ja metsäkaupungin ääripäänä. Kompaktikaupungin ympäristöön on liitetty usein kielteisiä mielikuvia ja puutarha- ja metsäkaupunkiin myönteisiä. Pyrimme artikkelissamme kuitenkin osoittamaan, että kuva ei ole mustavalkoinen. Myös maisemasuunnittelun rooli erilaisten luontokäsitysten materialisoijana on jäänyt sivuun, erityisesti metsä- ja kompaktikaupunkien osalta. Maisema-arkkitehtuurin asema erityisesti Tapiolan puutarhakaupungissa on tunnistettu jo laajasti, mutta myöhempien asuinalueiden maisemasuunnittelijoiden kädenjälkeä ei edelleenkään juurikaan tunneta. Artikkelimme lähtökohtana on, että kaupunkisuunnittelun erilaiset luontokäsitykset edellyttävätkin tarkempaa analyysia, jotta näiden periaatteiden mukaisesti rakennettuja alueita voidaan ymmärtää ja niiden ominaispiirteitä ja arvoja tunnistaa.

\section{Puutarhakaupunki - kalliometsiköitä,} puutarhapihoja ja maisemakontrasteja Sotien jälkeisenä aikana kaupunkisuunnittelusta tuli keskeinen osa hyvinvointivaltion toteuttamista. Voimakas jälleenrakentaminen ja uusien asuinalueiden, julkisten rakennusten ja tiestön rakentaminen olivat osa modernismin kansallista projektia, jonka aikana maatalousvaltainen Suomi uudenaikaistui ja alkoi teollistua. Kaupunkiseudut kasvoivat ${ }^{23}$ ja muuttuivat voimakkaasti. Kaupunkirakenteen muutosta siivitti myöhäisfunktionalismiin tukeutunut lähiörakentaminen, josta tuli Suomen vallitseva suunnitteluparadigma useiksi vuosikymmeniksi.

Suomalaisen puutarhakaupunkiajattelun tärkeimmät vaikutteet saatiin Ebenezer Howardin Englannin puutarhakaupungeista ja New Town -uuskaupungeista sekä Saksan Siedlung-asuinalueista. Myös Clarence Perryn lähiöteoria, Le Corbusier'n futuristiset kaupunkivisiot ja Lewis Mumfordin ideologinen suurkaupunkikritiikki vaikuttivat suomalaiseen suunnitteluun. ${ }^{24}$ Toisen maailmansodan jälkeistä kaupunkisuunnittelua ohjasivat erityisesti funktionalismi ja hajakeskitykseen perustunut lähiöteoria, jonka merkittävimpänä puolestapuhujana oli Otto-livari Meurman, Suomen ensimmäinen asemakaavaopin professori ja monipuolinen kaupunkisuunnittelun vaikuttaja. Meurmanin vuonna 1947 julkaiseman Asemakaavaopin mukaisesti asutus järjestäytyi 
hajakeskitysperiaatetta noudattaen erillisiksi vihervyöhykkeiden ympäröimiksi alueiksi (community), jotka jakaantuivat asumalähiöihin (neighbourhood unit) ja edelleen pienempiin asumasoluiksi kutsuttuihin yksikköihin (residential unit). ${ }^{25}$

Tapiolan puutarhakaupungin perustana oli arkkitehti Otto-livari Meurmanin laatima suunnitelma vuodelta 1945 . Malliyhdyskunnan suunnittelua ja rakentamista varten perustettiin Väestöliiton toimitusjohtajan Heikki von Hertzenin johdolla vuonna 1951 Asuntosäätiö. Tapiolassa yhdistyivät puutarhakaupungin kaksi keskeistä periaatetta: modernismin avoin korttelirakenne ja luonnonläheisyys. Se oli vastakohta keskustan ahtaille ja valottomille kivitalokortteleille sekä monotonisille omakotialueille, joita von Hertzen kritisoi voimakkaasti pamfletissaan Koti vaiko kasarmi lapsillemme (1945).

Merkittävässä roolissa Tapiolan luomisessa olivat viheralueista vastanneet puutarha- ja maisemaarkkitehdit. Tapiola oli ensimmäinen suomalainen asuinalue, jonka suunnitteluun puutarha- ja maisema-arkkitehdit osallistuivat laajamittaisesti arkkitehtien ja insinöörien rinnalla. Tapiolaa suunnittelivat nuoret puutarha-arkkitehdit, muun muassa Nils Orénto, Onni Savonlahti, MajLis Rosenbröijer, Carl-Johan Gottberg ja Jussi Jännes, joka oli heistä kaikkein tuotteliain. ${ }^{26}$ Heikki von Hertzenin visiossa kaupunki rakennettiin konkreettisesti osaksi maisemaa ja sen varaan. Maisemasuunnittelun johtoajatuksena oli olemassa olevan luonnon kunnioittaminen ja maiseman huolellinen tulkitseminen. ${ }^{27}$ Kallioiset alueet, jotka eivät soveltuneet asuinrakentamiseen, jätettiin luonnontilaan. Tapiolan suuret puistot, Leimuniitty ja Silkkiniitty, rakennettiin entisille niityille ja pelloille. Asumiseen liittyi pienipiirteinen ja rikas kerrostalo- ja rivitalopihojen puutarhamiljöö, joka vaihettui huomaamattomasti puistoihin. ${ }^{28}$ Nämä kolme erilaista luontotyyppiä - luonnontilainen metsä, puutarhamainen vyöhyke ja laajat puistoalueet muodostivat modernin asuinympäristön kokonaisuuden. Niistä jokaisella oli oma esteettinen sekä sosiaalinen tehtävänsä osana kaupunkiympäristöä.

Tapiolan maisemasuunnittelijat olivat suorittaneet opintoja ulkomailla ja omaksuneet vaikutteita modernismin maisema-arkkitehtuurista, esimerkiksi Malmön Frilufststadista (1944) ja Göteborgin Guldhedenistä (1945). ${ }^{29}$ Tapiolan suunnittelijoista esimerkiksi Jussi
Jännes opiskeli Tanskassa C.Th. Sørensenin johdolla ja hänen esikuvinaan oli tanskalaisen modernismin lisäksi modernin maisema-arkkitehtuurin pioneerit Thomas Church ja Roberto Burle Marx. ${ }^{30}$ Jännes hyödynsi kontrastisia maisema-arkkitehtonisia eleitä, jotka loivat vastakohdan olemassa olevan maiseman kanssa. Suunnittelu perustui moderniin, kansainvälisiä vaikutteita välittävään muotokieleen ja huomiota herättävän koristekasvillisuuden käyttöön. Maisema-arkkitehtuurin tuli näkyä ja erottua, samalla kun maisematilojen - puistojen, pihojen ja rakentamattomien luontoalueiden väliset rajat haluttiin häivyttää. ${ }^{31}$

Tapiolan maisema-arkkitehtuurin tunnetuimpana esimerkkinä on Jussi Jänneksen 1950-luvun lopulla suunnittelema Leimuniitty ja sen kirkasväriset perennaistutukset, joiden tarkoituksena oli toimia puutarhakaupungin tervetulotoivotuksena. Jännes kuvaakin itse, ettei Leimuniityn tarkoituksena ollut toimia varsinaisena oleskelupuistona Silkkiniityn tapaan. Luonteenomaista puistolle olivat värikkäät suuret leimukukkaistutukset, joiden taustana kohosivat vanhat petäjät. Tapa käsitellä kasvimateriaalia massoina, jotka muodostivat suuria, geometrisia väripintoja 
viittaa melko suoraan Roberto Burle Marxin ilmaisuun, joka tunnettiin abstrakteja maalauksia muistuttavista suunnitelmistaan. ${ }^{32}$ Jänneksen kasvimassat olivat myös ilmaus modernista elämäntavasta, jossa puutarhakaupunkiin saavuttiin autolla ja istutuskuviot nähtiin sopivalta korkeudelta, ohikiitävän ajoneuvon vauhdissa. ${ }^{33}$ Viljo Revellin suunnittelemien Länsikorkeen pistetalojen, ns. Taskumattien (1959-1961) pihaalueille Jussi Jännes suunnitteli tummanpunalehtiset hurmehappomarjaistutukset ja aniliininpunaiset sammalleimuistutukset kalliopainanteisiin korostamaan paikan karua luontoa. Jänneksen kontrastiset istutukset korostivat valkoisen, modernistisen arkkitehtuurin monumentaalisuutta. Matalat sammalleimut peittivät mattoina kalliopintoja ja muodostivat jälleen samankaltaisen, abstraktista maalaustaiteesta muistuttavan visuaalisen elementin erityisesti kerrostalon ikkunoista katsottuna. Kiinnostavaa on, että rajujen kontrastisten vaikutelmien sijaan yksityisille puutarhapihoille Jännes suunnitteli lajirikkaita, intiimejä ja lähes eksoottisen puutarhamaisia miljöitä. Kukkivat pienet puut ja seinäpinnoille kiipeävät köynnökset sekä perennat ja ikivih- reät kasvit laattapihan istutusalueissa pehmensivät ja ikään kuin vaatettivat talojen yksinkertaisen, pelkistetyn arkkitehtuurin linjoja. ${ }^{34}$
Kuva 1. Tapiolan puutarhakaupunki ja Leimuniityn maisemakontrasteja. Kuva: Atte Matilainen, Arkkitehtuurimuseo.
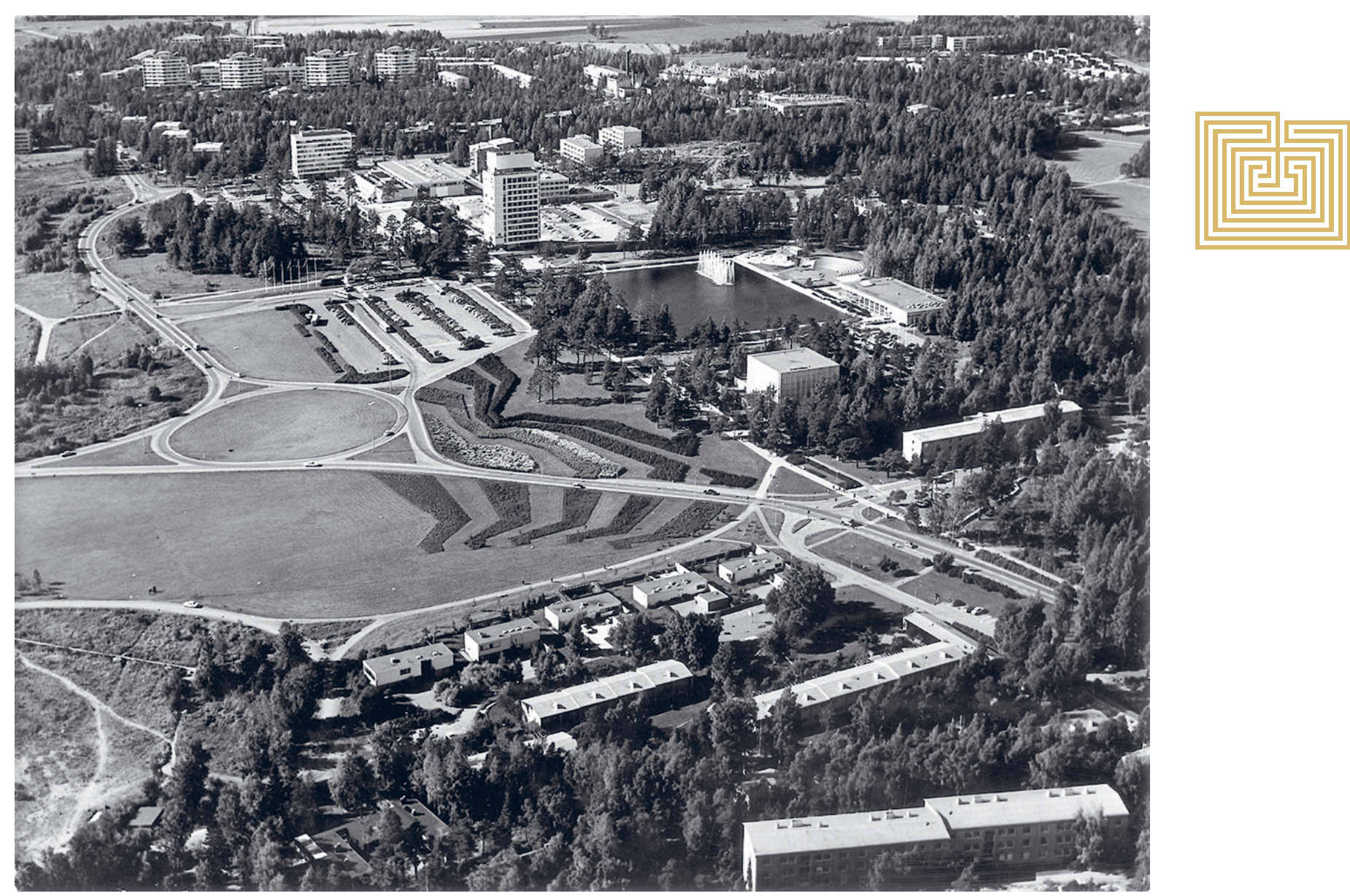


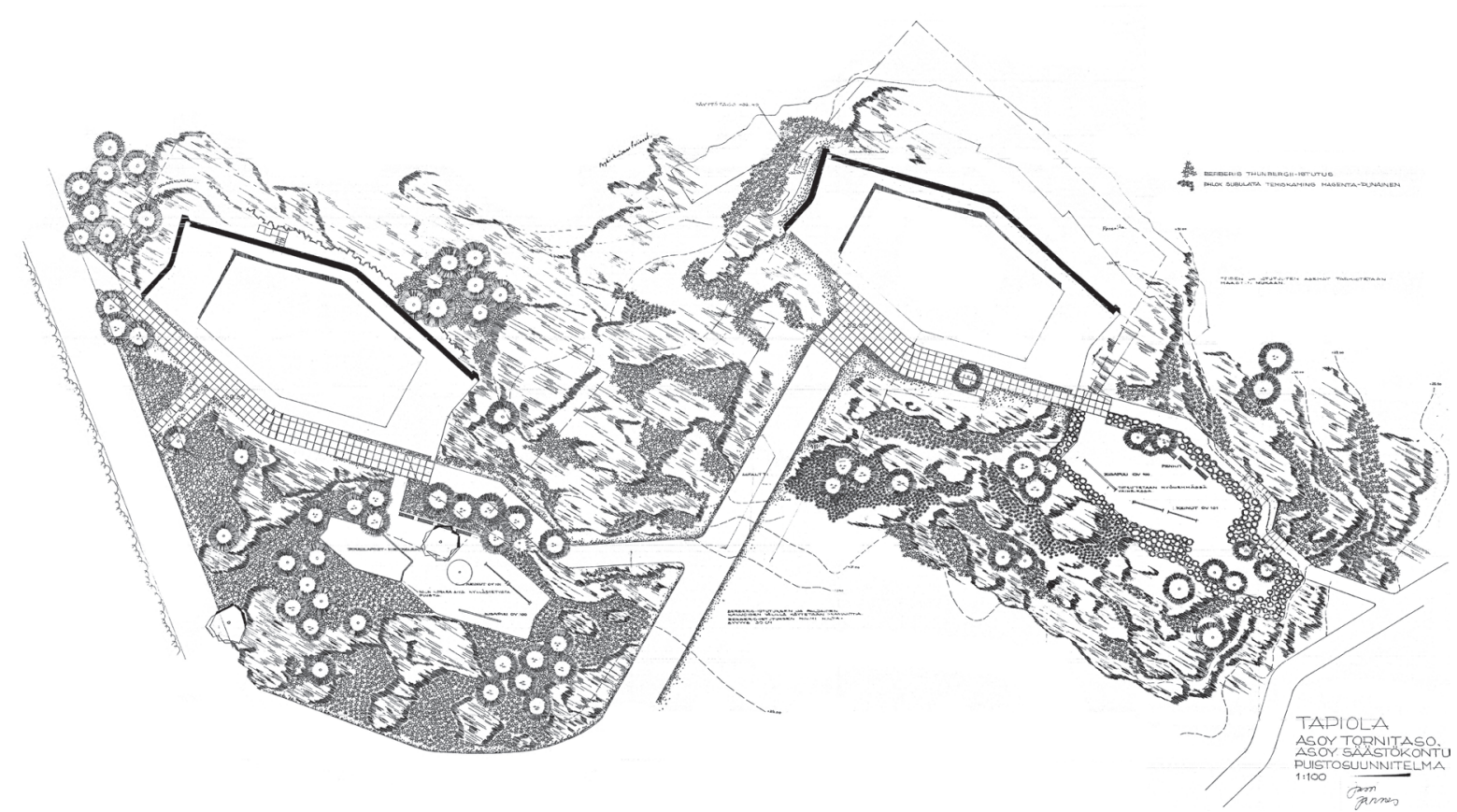

Kuva 2. Jussi Jänneksen laatima suunnitelma Tapiolan Länsikorkeelle, jossa värikkäät istutukset muodostivat biomorfisia kirkasvärisiä kuvioita karuun kalliomaisemaan. Kuva: Jussi Jänneksen piirrustuskokoelma, Arkkitehtuurimuseo. tökohtaisesti hyvin suomalaisena mallina. ${ }^{36}$ Vaikka metsäkaupunki kasvoi puutarhakaupungista ja toteutti sen monia ihanteita, sen luontosuhde oli kuitenkin erilainen. Verrattuna Tapiolan puistoihin ja puutarhoihin, metsäkaupunki korosti luonnontilaista luontoa. Luonnonläheisyydellä ja erityisesti metsällä oli suuri symbolinen merkitys, kun Suomen kaupungistuminen kiihtyi ja väestö muutti maalta kaupunkeihin. ${ }^{37}$ Metsäkaupungissa luonto otettiin haltuun hyvinvointia ja moraalisia arvoja tukevana tekijänä sekä esteettisenä ihanteena. ${ }^{38}$ Se heijastui myös arkkitehtuuriin: rakennusten sijoittamisessa otettiin huolellisesti huomioon maisema, maastonmuodot, puusto ja ilmansuunnat.

Esimerkkikohteeksi valitun Vuosaaren suunnittelu käynnistyi 1950-luvulla ja noudatti Meurmanin Asemakaavaopin lähiöperiaatteita. Vuosaaren kaava oli väljä ja jokaista rakennettua suinkerrosneliömetriä vastasi sama määrä viheraluetta. Alueen maisemasuunnitteluun kiinnitettiin erityistä huomiota. Suurimman rakennuttajan, Asuntosäästäjät ry:n palkkaamana suunnittelijana toimi maisema-arkkitehti Katri Luostarinen, joka tunnettiin kokeneena asuinalueiden suunnittelijana ja myöhemmin maisemasuun- 
nittelun ensimmäisenä apulaisprofessorina. ${ }^{39}$ Alueen identiteetti rakentui markkinoinnissa voimakkaasti luonnonympäristön varaan: "Vuosaaressa on runsaasti koskematonta metsää, vehmaita rantoja ja idyllisiä metsälampia. Alueen asemakaavassa on seudun luonnonläheinen suhde pyritty säilyttämään niin suuressa määrin kuin mahdollista." ${ }^{" 40}$ Rakennuskaavan päämääränä oli säilyttää ja korostaa alueen olemassa olevaa luontoa: kallioita, metsää ja vanhoja viljelysmaita. Korkeimmat kallioalueet ja alavimmat maastonkohdat säästettiin puistoiksi, kerrostalorakentaminen sijoitettiin rinteisiin ja peltoaukeiden reunoille rakennettiin puolestaan rivitaloja. Istutettavia puistoja merkittiin ainoastaan kaistoina pääkatujen molemmin puolin. ${ }^{41}$

Vuosaaren metsäkaupungin maisemasuunnittelussa luonto jäsentyi erilaisiksi esteettisiksi ja toiminnallisiksi tyypeiksi luonnontilaisista alueista hoidettuun luontoon ja puutarhamaisiin miljöisiin. Asuinkerrostalojen pihojen toimintojen huolellisella suunnittelulla pyrittiin säästämään rakennuksia ympäröivää luonnontilaista ympäristöä. ${ }^{42}$ Pihasuunnittelussa korostuivat pyrkimykset luonnonmaiseman elementtien soveltamisesta osaksi kerrostalojen pihamiljöitä. Esimerkiksi Katri Luostarisen laatimassa Sääs- tömaston suunnitelmassa pihasommitelma rakentuu ison kallion reunaan. ${ }^{43}$ Korttelin 64 suunnitelmassa korttelin keskiosassa oli "ahoniitty" ja tonttia ympäröivä "metsätyyppinen luonto" jatkui hoidettuna puistokaistaleena tontin keskialueen halki. Istutettaviksi merkityt kuivan kankaan kasvit ja muut luonnonkasvit siirrettiin metsästä, kylvettiin siemenistä tai hankittiin metsätaimina. Perinteisiä puutarhan koristekasveja istutettiin vain rakennusten lähituntumaan. ${ }^{44}$ Rivitalojen modernien, pienten "laattapihojen” tyyppipiirustuksiin Luostarinen sijoitti istutettavaksi perinteisempien puutarhakasvien oheen myös tyrnipensaita. ${ }^{45}$

Katri Luostarinen arvosti erityisesti suomalaista luontoa ja edusti näkemystä, jonka mukaan paikan alkuperäisten luonnonpiirteiden tuli toimia suunnittelun lähtökohtana. Hänen mukaansa tulevaisuuden puistokysymys on kaupungeissa enemmän maisemien säilyttämistä ja kehittämistä kuin taidokkaiden puistokuvioiden luomista. ${ }^{46}$ Luostarinen artikuloi käytännönläheisellä tavalla ajatusta hyvinvoinnista ja suomalaisten erityisestä luontosuhteesta, jolle muutkin - arkkitehdit ja kirjoittajat etsivät sopivaa, modernia muotoa. Luonnon ja luonnonläheisyyden nähtiin tuottavan sosiaalista hyvinvointia. "Koti luonnossa" oli kaupunkiin muuttavalle väestölle side entiseen elämänpiiriin tai paremman elämän mahdollisuus kantakaupungin ahtaissa ja puutteellisissa oloissa asuvalle työväestölle. Luostarisen pihasuunnittelun tavoitteena ${ }^{47}$ oli perinteisten arvojen muokkaaminen modernia elämäntapaa vastaavaan muotoon. Piha juurrutti ihmisen asuinpaikkaansa ja kotiseutuunsa. ${ }^{48}$

Luostarisen suomalaisen maiseman ja luonnon arvoa korostavan suunnittelunäkemyksen taustalla oli pitkä kansainvälinen keskustelu, jonka juuret olivat jo 1800-1900-lukujen vaihteessa käydyssä kiistassa formaalin ja luonnonmukaisen suunnittelutavan paremmuudesta. ${ }^{49}$ Saksassa opiskelleeseen Luostariseen oli vaikuttanut epäilemättä sikäläisen maisema-arkkitehtuurin suhde kotimaan maisemaan ja pyrkimys laajojen maisemakokonaisuuksien ymmärtämiseen. ${ }^{50}$ Maiseman ominaispiirteiden korostaminen oli tunnusomaista myös Tukholman puistotyylissä, joka piti lähtökohtanaan luonnonmaisemaa ja hylkäsi formaalit tai pittoreskit esikuvat. ${ }^{51}$ Luonnonmaiseman ihannoiminen ulottui myös kasvimateriaaliin: Amerikassa ja muualla Euroopassa puolustettiin voimakkaasti kotimaisen kasvillisuuden käyttöä ja vastustettiin puutarhasuunnittelussa vallinnutta yleistä vierasperäisten lajien suosimista ja samaa keskustelua käytiin Suomessakin. ${ }^{52}$ 


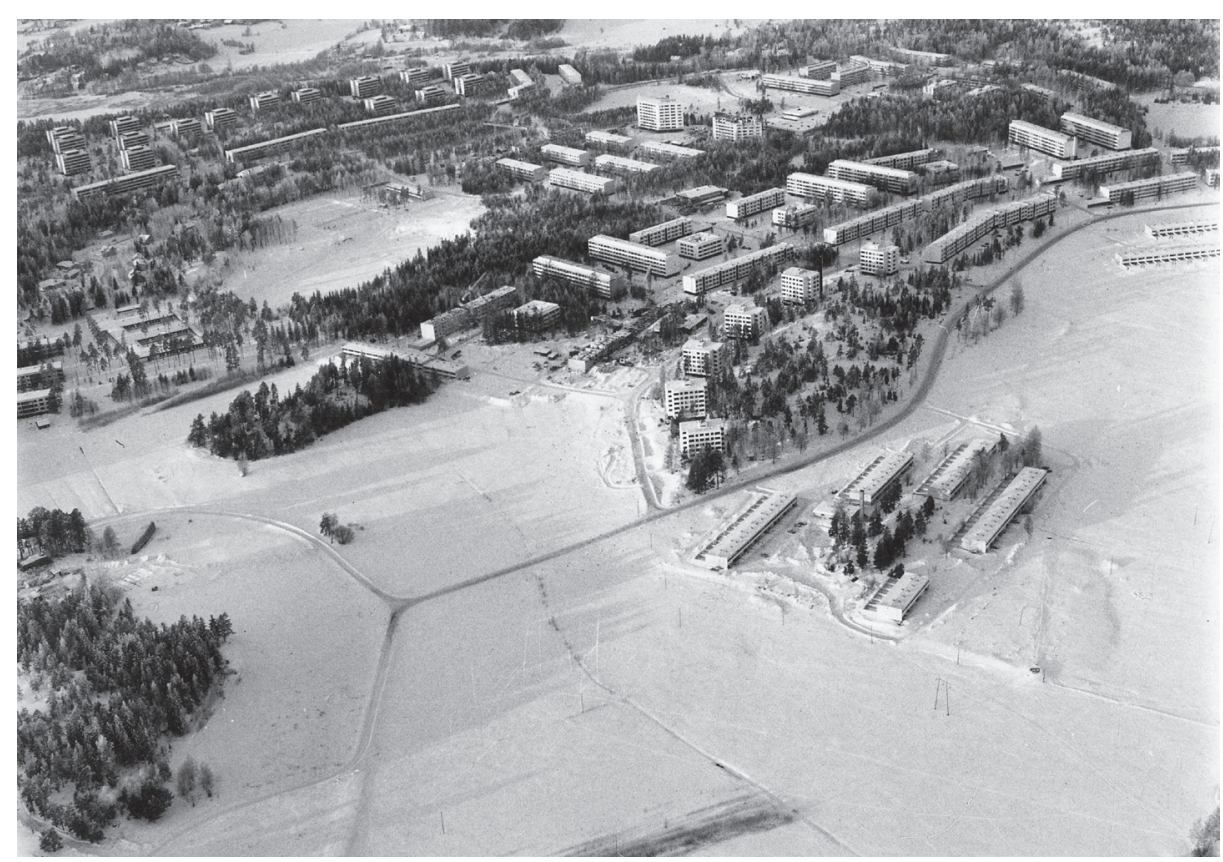

Kuva 3. Keski-Vuosaaren metsäkaupungissa rakentaminen sijoitettiin huolellisesti maisemaan. Kuva: Arkkitehtuurimuseo.

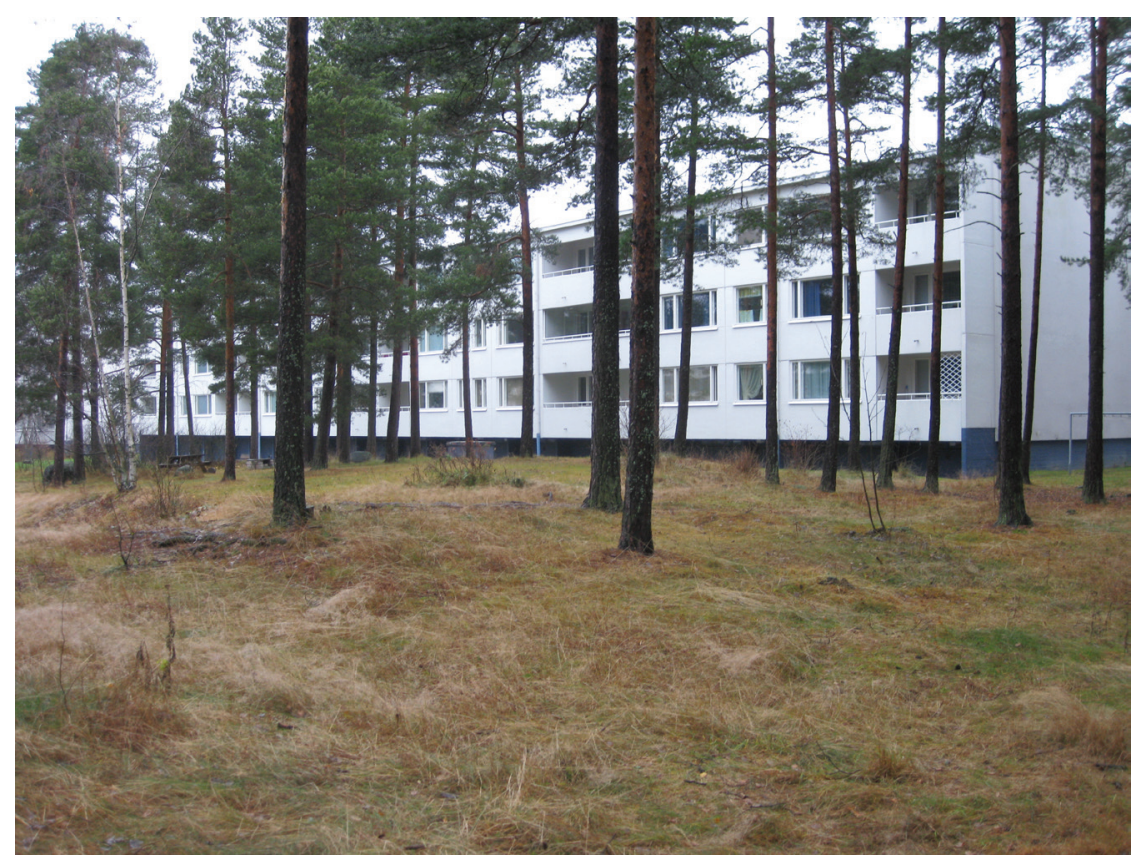

Kuva 4. As Oy Kivisaarentien metsäpiha Keski-Vuosaaressa. Luonnontilainen mäntymetsä soljuu rakennusten lomaan. Kuva: Meri Mannerla-Magnusson.

\section{Kompaktikaupunki - sosiaalinen ja rati- onaalinen rakennettu kaupunkivihreä}

Kaupunkisuunnittelun ihanteet tekivät 1970-luvulle tultaessa täyskäännöksen. Teollistuminen ja rakentamisen rationalisoimisvaatimukset johtivat 1960-luvun loppua kohden rakennustekniikan uudistumiseen ja tuotannon tehostamiseen. Tehostunut asun- totuotanto vastasi kasvavaan asuntopulaan ja yhteiskunnan rakennemuutoksen vuoksi maalta kaupunkiin muuttavan väestön asuttamiseen. ${ }^{53}$ Väljä metsäkaupunki korvautui urbaanilla ja tiiviillä ruutukaavalla, joka toteutti paremmin tehokkuuden vaatimuksia. Uutena ohjenuorana oli strukturalismi, joka pohjautui elementtirakentamista ja sarjatuo- tantoa palvelevaan moduuliruudukkoon. Elementtiteknologia kasvatti myös rakennustehokkuutta ja rakennusten korkeutta sekä muutti ulkoarkkitehtuuria. Struktuuriajattelu johti myös entistä laajempien aluekokonaisuuksien toteuttamiseen. ${ }^{54}$

Kompaktikaupungin tiiviys tähtäsi myös uudenlaiseen kaupunkikulttuuriin ja toimi- 
viin palveluihin, joiden nähtiin puuttuvan metsäkaupungista. Tunnuslause "kompaktikaupunki on kontaktikaupunki" ilmensi kaupunkisuunnittelun pyrkimyksiä luoda yhteisöllisyyttä ja tiloja kohtaamiselle. Sen mukaisesti intiimi, tiiviisti rakennettu ympäristö tukee jalankulkua ja risteävät reitit synnyttävät luonnollisia kohtauspaikkoja, positiivisia törmäyspisteitä. ${ }^{55}$ Kontaktikaupungin idea vaikutti myös viheralueisiin ja asuinalueiden luontoon. Kriitikot näkivät metsäkaupungin luonnon individuaalisuutta korostavana ja sosiaalista kanssakäymistä heikentävänä. ${ }^{56}$ Kompaktikaupungin suhde luontoon oli monessa mielessä metsäkaupungin vastakohta. Kun metsäkaupungissa rakennukset sijoitettiin orgaanisesti maisemarakennetta ja topografiaa noudattaen, kompaktikaupungin moduuliruudukko muodosti maiseman kanssa kontrastin, joka parhaimmillaan loi kiinnostavan vuoropuhelun, mutta monesti jätti suurelta osin huomioimatta rakennuspaikan luontotekijät. ${ }^{57}$ Olemassa olevan maiseman ja luonnon hyödyntämisen korvasi suunniteltu ja istutettu kaupunkivihreä, jonka toiminnat olivat esteettisiä ominaisuuksia tärkeämpiä. Luonnontilainen luonto ymmärrettiin elementtinä, joka ei kuulu kaupunkiin. ${ }^{58}$
Esimerkkikohteeksi valitun Itä-Pasilan asemakaava (1971) muodostui yhtenäisestä, lähes koko alueen kattavasta ruutuverkosta, joka mahdollisti sarjatuotannon, tonttien käyttötarkoituksen joustavan muuttamisen ja vaiheittaisen rakentamisen. ${ }^{59}$ Itä-Pasilan suunnittelussa heijastuivat kaupunkisuunnittelun uudet sosiaaliset ja rationaaliset tavoitteet. Asukkaiksi tavoiteltiin inmisiä, joille palvelut ja aktiivinen, kaupunkimainen elämä olivat asumisen tärkein arvo. ${ }^{60}$ Itä-Pasilan ruutukaavan ja tiiviin korttelirakenteen nähtiin edistävän sosiaalisesti aktiivisen ja inmisten kohtaamisiin "pakottavan" kaupunkiympäristön syntymistä. ${ }^{61}$ Hyvinvointivaltion rakentamisen tavoitteet heijastuivat siten erityisesti kaupunkirakenteen sosiaalisen ulottuvuuden uudistamisessa.

Itä-Pasilan viheralueiden suunnitteluun palkattiin maisema-arkkitehti Leena lisakkila, jolla oli vankka kokemus asuinalueiden suunnittelusta pääkaupunkiseudulla ja joka toimi 1970-luvulla Teknillisessä korkeakoulussa vt. maisemasuunnittelun apulaisprofessorina. $^{62}$ lisakkila ei ollut mukana vielä kaavoitusvaiheessa eikä päässyt siten vaikuttamaan maankäytön perusratkaisuihin. ${ }^{63}$

Tämä oli vielä hyvin tavallista 1970-luvun alkupuolella, vaikka kansainvälisesti laaja-alai- nen, kaavoitusta ohjaava maisemasuunnittelu oli vahvasti esillä Ian McHargin uraauurtavan teoksen Design with Nature (1969) ansiosta. ${ }^{64}$ lisakkilan omien sanojen mukaan Itä-Pasilan maisema tuntui rakentamisen alkuvaiheessa pelottavalta, sillä luonnonmaisema oli kokonaisuudessaan hävinnyt. Puu-Pasilan pientaloalueen puutarhat olivat kadonneet, ja alkuperäistä kalliota onnistuttiin kansirakentamisen vuoksi säilyttämään vain alueen reunoilla ja pieninä nyppylöinä korttelipihoilla. Kaupunkivihreä tuli rakentaa alueelle kokonaisuudessaan uudelleen ja "kaikki oli suunniteltava uuden kaupunginosan ideologisilla ehdoilla ja uutta, istutettua kasvillisuutta käyttäen". ${ }^{65}$ Tavoitteena oli luoda alueelle erittäin reheviä, pienimittakaavaisia ympäristöjä ja pehmeyttä kontrastiksi massiiviselle betonirakentamiselle. ${ }^{66}$ Koska viheralueita ja ulkoilualueita oli vähemmän kuin asuinalueille yleensä, "tehokkaiden vihermassojen" oli määrä korvata pienet viherpinta-alat. ${ }^{67}$

Itä-Pasilaan suunnitellun tiiviin korttelirakenteen ja liikennejärjestelyjen kävelykansineen visioitiin olevan "suojattu ja turvallinen pikkuparatiisi kävelyverkostoineen, istutuksineen ja kauppoineen". ${ }^{68}$ Maisemasuunnittelussa pyrittiin luomaan miellyttävät kehykset 
sosiaalisille kontakteille ja inmisten välisille kohtaamisille. Suunnittelun perustana olivat hierarkkiset, erilaisiin toimintoihin perustuvat vapaa-alueet. ${ }^{69}$ Esimerkiksi Tyyppipiha-suunnitelmissa kerrostalopihoja varten esitettiin tiloja eri-ikäisten asukasryhmien toiminnalle, kuten shakinpeluulle, hiekkaleikille ja aikuisoleskelulle. ${ }^{70}$ Pihasuunnitelmien geometrinen muotokieli heijasti struktuurikaupungin henkeä ja Tanskassa Sven Ingvar Anderssonin johdolla opiskelleen lisakkilan pyrkimystä yksinkertaisuuteen ja tarkoituksenmukaisuuteen. ${ }^{71} \quad$ Kokonaisvaltaisesta suunnitteluotteesta kertoi koko kaupunginosalle laadittu virkistysaluejärjestelmä, jossa oli eritelty kortteli-, kaupunginosa- ja urheilupuistot sekä leikkipaikat ja pihat. Eri viheralueet oli kytketty toisiinsa jalankulkuväylin. ${ }^{72}$ Hierarkkisesti jäsennöity virkistysaluejärjestelmä ilmensi 1970-luvun analyyttista suunnittelutapaa, jonka tuloksena syntyivät myöhemmin suunnittelua ohjaavat standardit ja leikkipaikkojen ja ulko-oleskelutilojen määrälliset pinta-alavaatimukset. ${ }^{73}$

Itä-Pasilan syntyprosessi liittyi uuden arkkitehtisukupolven "löysän väljien puutarhakaupunkien kritiikkiin" ja alueen suun- nittelua leimasi tarve uuden etsimiseen. Tavoitteena oli käveltävä kaupunki, joka toteutui kuitenkin riisuttuna versiona ilman hihnakuljettimia, lämmitettyjä jalkakäytäviä ja monia sosiaalisiksi kohtaamispaikoiksi suunniteltuja tiloja. Itä-Pasilasta käyty keskustelu muodostui mustavalkoiseksi alueen ihailuksi taikka sen täydelliseksi tyrmäämiseksi. Aluetta joko kiitettiin uuden kaupunkirakentamisen voimannäytteenä tai pidettiin kolkkona ja ankeana leveine katukuiluineen. ${ }^{74}$ On kuitenkin kiinnostavaa, että asukkaiden kokemuksissa alue on vehreä ja viihtyisä. ${ }^{75}$ Kaupunkivihreä on muodostunut ajan kuluessa karun rakennetun ympäristön vastakohdaksi, vaikka vihreys onkin vuosikymmenien kuluessa kasvanut lisakkilan mukaan liiankin reheväksi. ${ }^{76}$

\section{Kaupungin muuttuvat luonnot}

Keskustelu luonnosta ja ristiriitaiset luontokäsitykset ilmenevät selvästi suomalaisessa kaupunkisuunnittelussa 1950-luvulta 1970-luvulle. Vaikka kaikki luontotyypit tavoittelivat hyvinvointia ja laatua, käsitykset oikeasta toteutustavasta vaihtelivat suuresti. Puutarha- ja metsäkaupungissa luonto nähtiin olennaisena osana kaupunkia ja maisemasuunnittelu keinona luonnon esteettisten ja sosiaalisten arvojen esiintuomiseksi. Puutarhakaupungissa suunniteltu ja muokattu luonto oli etusijalla. Kuten Tapiolan esimerkki osoittaa, erilaiset, eriasteisesti maiseman kanssa kontrastissa olevat puutarha- ja puistoelementit olivat keskeisiä. Kaupungistumisen kiihtyessä 1950-luvulla ajatus luonnonläheisyydestä tulkittiin toisin. Metsä ja ainakin näennäisesti muokkaamaton ympäristö tuli modernia, muokattua ja ehkä keinotekoiseksikin koettua puistomaisemaa merkityksellisemmäksi. 1960-luvun kuluessa väljän luonnonläheisyyden ihanne vaihtui täysin vastakkaiseksi. Kompaktikaupungissa tavoitteena oli sosiaalinen ja tilallinen tiiveys, jossa asukkaiden hyvinvointi rakentui inmisten välisissä kohtaamisissa. Suunniteltu ja rakennettu kaupunkivihreä toimi taustana kompaktikaupungin sosiaaliselle elämälle.

Maisemasuunnittelun merkityksellisyyttä 1950-1970-lukujen kaupunkisuunnittelussa on tutkittu melko vähän, mikä kaventaa ymmärrystä sodanjälkeisestä asuinaluesuunnittelusta ja maisema-arkkitehtuurin muotoutumisesta itsenäiseksi professioksi kaupunkisuunnittelun rinnalle. Tapiolan puutarhakaupunki jäi laajuudessaan ja kunnianhimossaan ainutlaatuiseksi hankkeeksi, 


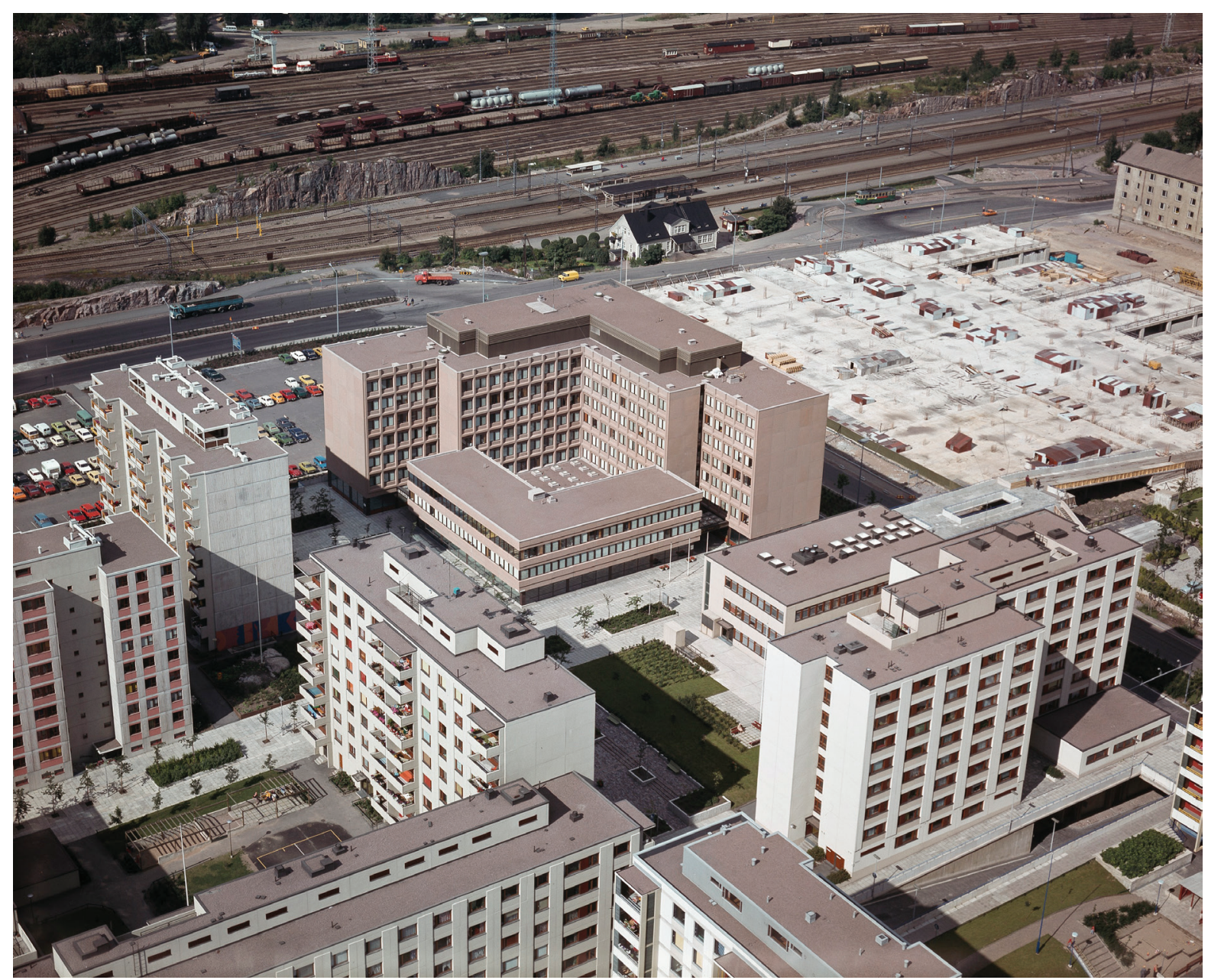

Kuva 5. Itä-Pasilan rakennettua kaupunkivihreää vuonna 1977. Ruutukaava, tiivis korttelirakenne ja pienet puistikot edistivät sosiaalisia kohtaamisia. Kuva: SKY-FOTO Möller, Helsingin kaupunginmuseo. jossa maisemasuunnittelu nousi näkyvään rooliin arkkitehtuurin rinnalle. Tapiola avasi oven suomalaiselle modernille maisema-arkkitehtuurille, ja sen perintö välittyi sodanjälkeisiin metsäkaupunkeihin. Vaikka metsäkaupungeissa maisema-arkkitehtien kädenjälki oli visuaalisesti huomaamattomampaa kuin Tapiolassa, heidän työnsä edisti kuitenkin luonnontekijöiden ja puuston huomioonottamista ja viihtyisämpien asuinympäristöjen toteutumista. Kun rakentamisen volyymi kasvoi, maisema-arkkitehtien tehtäväkenttä laajeni ja myös vaikeutui vaativien rakennushankkeiden myötä. Tiivis kompaktikaupunki teknisine kansirakenteineen ja istutusaltaineen oli vehreän asuinympäristön toteuttamisen kannalta metsäkaupunkia huomattavasti haastavampi. 1970-luvulla yleistyneet asuinympäristön ja pihojen suunnittelua koskevat ohjeet ja normit pyrkivät ohjaamaan laajentuvaa suunnittelun kenttää ja edistivät samalla maisemasuunnittelun vakiintumista osaksi kaupunkisuunnittelua. Kehitystä tuki myös voimistunut ympäristöliike ja ympäristöongelmien tunnistaminen, mikä loi pohjaa ekologiselle suunnittelulle. ${ }^{77}$

Puutarha-, metsä- ja kompaktikaupunkien vihreä perintö edellyttää lisätutki- 


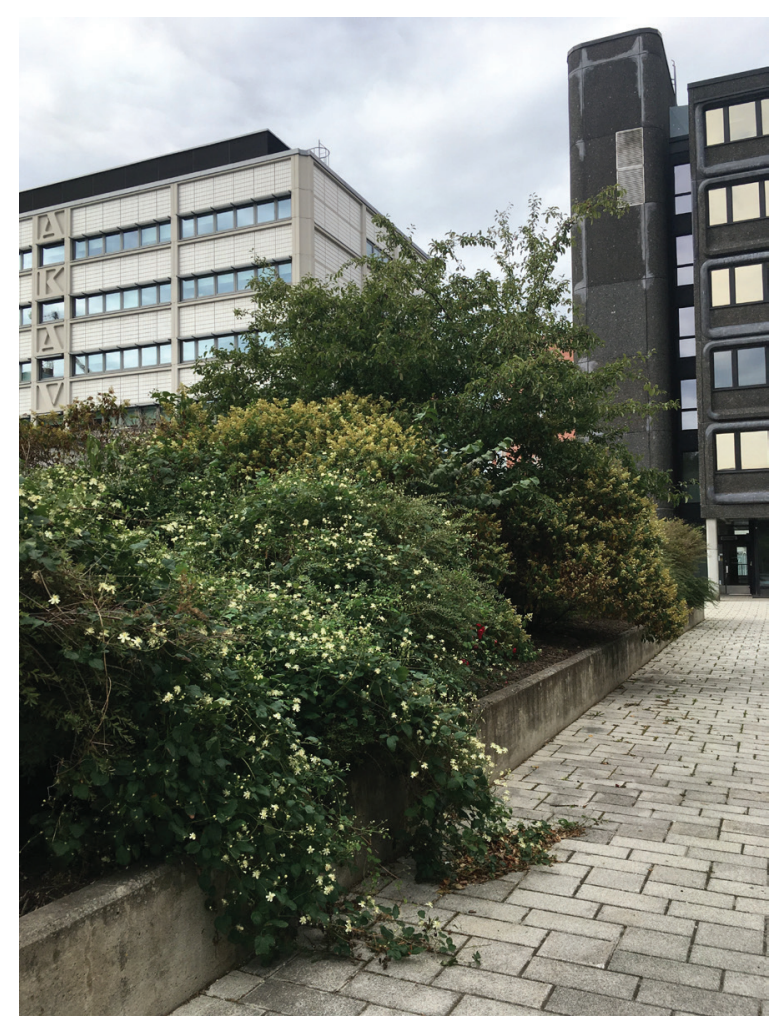

Kuva 6. Itä-Pasilan kansipihojen vehreyttä. Kompaktikaupungin pihat ja puistot loivat pehmeyttä massiiviselle betonirakentamiselle. Kuva: Julia Donner. musta mutta myös uudelleenarviointia. Vaikka 1950-70-luvulla etsittiin hahmoa nimenomaan suomalaiselle ilmaisulle maisema-arkkitehtuurissa, kehitykseen heijastui myös kansainvälinen keskustelu. Nämä kansainväliset kytkökset ja modernin suomalaisen maisema-arkkitehtuurin vaikutteet ovat kuitenkin pitkälti kartoittamatta. Myös arkkitehtuurin ja maisema-arkkitehtuurin suhteen tarkempi analyysi vaatii lisätutkimusta. Esimerkkikohteet osoittavat, että vaikka maisema-arkkitehtuuri seurasikin asemakaavoituksen asettamaa kehystä, sillä oli kuitenkin merkittävä ja itsenäinen rooli ympäristön muotoutumisessa. Maisema-arkkitehtuuri vastasi kaupunkivihreän muodonannosta, sisällöstä ja toiminnoista. Maisema-arkkitehtuurin ja arkkitehtuurin vuoropuhelu ansaitsisi kuitenkin enemmän huomiota tutkimuksessa.

Uudelleenarviointi koskee myös eri kaupunkityyppien arvottamista. Kaupunkityypit esitetään usein melko mustavalkoisina - joko hyvinä tai huonoina kaupunkiympäristön esimerkkeinä, riippuen vallalla olevista mieltymyksistä ja näkökulmasta. Maisemasuunnittelun kannalta tarkasteltuna kuva voi näyttää toisenlaiselta. Esimerkiksi puutarha- ja met- säkaupunkeihin kohdistunut kritiikki inmisten välisten kontaktien vähenemisestä vaikuttaa perusteettomalta. Tapiolan ja Vuosaaren esimerkit osoittavat, että maisemasuunnittelussa ympäristön sosiaalisiin ulottuvuuksiin kiinnitettiin erityisesti huomiota. Toisaalta luonnonläheiseksi ja viihtyisäksi kiitetty metsäkaupunki saattoi toisenlaisena toteutuksena olla karu, kulunut ja hoitamaton. Maisemasuunnittelijat eivät aina olleet mukana metsälähiöiden suunnittelussa, suunnitelmat jäivät usein toteutumatta ja viheralueet hoitamatta. Rakennuksia ympäröivä käsittelemätön, luonnontilainen ympäristö ei kestänyt kovaa kulutusta ja ympäristön karuus korostui. Myös kompaktikaupungin myöhempiä arvioita tulee tarkastella uudelleen. Vaikka kompaktikaupungin elementtirakentaminen keskittyi usein määrällisiin tavoitteisiin laadullisten kustannuksella, kaupunkivihreän käsittely oli parhaimmillaan kuitenkin monipuolista ja huolellisesti suunniteltua, maisema-arkkitehtien työn tulosta, kuten Itä-Pasilan esimerkki osoittaa. Kompaktikaupunki oli monesti mainettaan vehreämpi ja viihtyisämpi. Sen sijaan se ei aina pyrkimyksistään huolimatta tuottanut sosiaalisia kohtauspaikkoja, vaan puutteellinen toteutus 
ja palvelutarjonta johtivat kuitenkin päinvastaiseen kehitykseen.

Kaupunkisuunnittelun luontokäsitys on muuttunut ja muuntuu jatkuvasti. Erilaiset tulkinnat tulevat näkyviksi juuri maisema-arkkitehtuurissa ja eri aikakausien viherympäristöissä. Ne tuovat esille kaupunkiluonnon hybridimäisen luonteen ja sen eriasteiset muunnelmat kulttuurisesta ja luonnollisesta luonnosta. Puutarha-, metsä- ja kompaktikaupungin luonnot ilmentävät kaupungin ja luonnon moniulotteista suhdetta ja tekevät omalta osaltaan kaupunginosista erityisiä ja omaleimaisia. Näiden ominaisuuksien tunnistaminen ja säilyttäminen on olennainen osa kaupunginosien vaalittavaa kulttuuriperintöä. Puutarhakaupungin puistot ja luonnon eri vyöhykkeet, metsäkaupunkien luonnonläheisyys ja väljyys ja kompaktikaupungin pienpiirteinen kaupunkivihreä täydentävät kaikki osaltaan kuvaa monipuolisesta kaupunkiluonnosta. Kaupunki ei rakennu siten vain yhdestä luonnosta vaan moninaisista luontokäsityksistä sekä kaupunkivihreän monimuotoisuudesta.

\section{Viitteet}

1 Maunu Häyrynen, Maisemapuistosta reformipuistoon. Helsingin kaupunkipuisto ja puistopolitiikka 1880-luvulta 1930-luvulle (Helsinki: Helsinki-Seura, 1994), 210; Maria Kaika, City of Flows. Modernity, Nature, and the City (New York: Routledge, 2005), 11-26.

2 Raymond Williams, "Luontokäsitykset", teoksessa Luonnon politiikka, toim. Yrjö Haila ja Ville Lähde

(Tampere: Vastapaino, 2003), 62

3 Ulla Salmela, Urban space and social welfare. Ottolivari Meurman as a planner of Finnish towns 19141937 (Helsinki: Taidehistorian seura, 2004), 22-23. 4 Riitta Hurme, Suomalainen lähiö Tapiolasta Pihlajamäkeen (Helsinki: Societas scientiarum Fennica, 1991); Timo Tuomi (toim.), Tapiola, elämää ja arkkitehtuuria / Tapiola - Life and Architecture (Helsinki: Rakennustieto, 2003); Riitta Nikula (toim.), Sankaruus ja arki - Suomen 50-luvun miljöö / Heroism and the Everyday - Building Finland in the 1950s (Helsinki: Suomen rakennustaiteen museo, 1994).

5 Jussi Jännes, "Tapiolan maisemahuollosta ja puutarhasuunnittelusta. Pyrkimyksiä ja kokemuksia", Asuntopolitiikka 4/1964, 4-7; Jussi Jännes, "Kontionkenttä", Arkkitehti 4-5/1964, 14-15. 6 Ks. esim. Annikki Savonlahti, "Asumalähiön ihanuus ja kurjuus", Puutarha 10/1967, 412-413; O. Larsson, "Suuret kasviryhmät massaistutukset", Puutarha 10/1967, 408-409. Molemmat Tampere: Tampereen puutarhaseura.

7 Emilia Weckman et al., Keski-Vuosaari. Maisemaja kaupunkikuvallinen selvitys (Helsinki: Helsingin kaupunki, 2006); Päivi Hellman ja Pia-Liisa Orrenmaa, Keski-Vuosaari-Korjaustapaohjeet (Helsinki: Helsingin kaupunki, 2010).

8 Lähiöitä on tutkittu taidehistorian lisäksi myös muilla tieteenaloilla: $\mathrm{mm}$. Irene Roivaisen sosiologian väitöskirja (1999) Sokeripala metsän keskellä ja Eveliina Asikaisen ympäristöpolitiikan väitöskirja
(2014) Luontopolitiikka lähiössä. Lähiöluonnon muotoutuminen Tampereen Hervannassa ja Vuoreksessa.

9 Stephanie Ross, "Paradokseja ja arvoituksia", teoksessa Paradokseja paratiisissa, toim. Arto Haapala ja Mia Kunnaskari (Helsinki: Erikoispaino, 2006), 20

10 Petteri Kummala, Tämä ei ole luontoa! Hybridi, ympäristön luovuus ja urbaani monimuotoisuus. Kaupunkiluonnon esteettiset ulottuvuudet Helsingin keskustan kaupunkitilassa (Helsinki: Helsingin yliopisto, 2016)

11 Bruno Latour, Emme ole koskaan olleet moderneja (Tampere: Vastapaino 2006), 8.

12 Anne Whiston Spirn, The granite garden, urban nature and human design (New York: Basic Books, 1984), 4.

13 Michael Bennett \& David W. Teague, The nature of cities, ecocriticism and urban environments (Tucson: University of Arizona Press cop., 1999), 10.

14 Ross, "Paradokseja ja arvoituksia", 26-30.

15 Ks. myös Kummala, Tämä ei ole luontoa!, 74

16 Ylva Uggla, "Construction of "nature" in urban

planning: A case study of Stockholm", Town Planning Review 2012 83:1, 69-85.

17 Matthew Gandy, Concrete and Clay: Reworking

Nature in New York City (MIT Press, 2002), 7.

18 Ellen Braae \& Henriette Steiner, "The role of Landscape Architecture Research", teoksessa Routledge Research Companion to Landscape Architecture, toim. Ellen Braae \& Henriette Steiner (Routledge, 2018), 1-2.

19 Bruno Braun \& Noel Castree (eds.), Remaking Reality: Nature at the Millennium (London, New York: Routledge,1998); Kaika, City of Flows.

20 Kaika, City of Flows, 13,18.

21 Trausti Valsson, City and Nature - An Integrated Whole (Reykjavík: Háskólaútgáfan, 1999), 37-68.

22 Ks. myös Virpi Hirvensalo, Modernin kaupungin luonto muutoksessa - kahdeksan esimerkkiä suomalaisesta asuinaluesuunnittelusta (Turku: Turun 
yliopisto, 2006), 235-240.

23 Hirvensalo, Modernin kaupungin luonto muutoksessa, 98-99.

24 Hurme, Suomalainen lähiö Tapiolasta Pihlajamäkeen, 12-54.

25 Otto-livari Meurman, Asemakaavaoppi (Helsinki:

Otava, 1947), 78-79.

26 Ria Ruokonen, "Maisema-arkkitehtuuri osana

kaupunkirakentamista Tapiolassa", teoksessa Unelma

paremmasta maailmasta. Moderni puutarha ja

maisema Suomessa 1900-1970, toim. Jyrki Sinkkilä,

Julia Donner ja Meri Mannerla-Magnusson (Helsinki:

Aalto Arts Books, 2016), 207.

27 Ruokonen, "Maisema-arkkitehtuuri osana

kaupunkirakentamista Tapiolassa", 212-214.

Katso myös Jännes, "Tapiolan maisemahuollosta

ja puutarhasuunnittelusta", 6; Onni Savonlahti, As.

Oy Nallenpolku, pihasuunnitelma 1966, MFA; Jussi

Jännes, piha Ilves, 1963, MFA.

28 Ruokonen, "Maisema-arkkitehtuuri osana

kaupunkirakentamista Tapiolassa", 209-210.

29 Ruokonen, "Maisema-arkkitehtuuri osana

kaupunkirakentamista Tapiolassa", 209.

30 Ruokonen, "Maisema-arkkitehtuuri osana

kaupunkirakentamista Tapiolassa", 211.

31 Jännes, "Tapiolan maisemahuollosta ja

puutarhasuunnittelusta", 5-6.

32 William Howard Adams, Roberto Burle Marx. The Unnatural Art of the Garden (New York: The Museum of Modern Art, 1991).

33 Jännes, "Tapiolan maisemahuollosta ja

puutarhasuunnittelusta", 5 .

34 Meri Mannerla-Magnusson, Julia Donner ja Minna Raassina, "Tapiola ja sen jälkeinen aika.

Metsäpuistoja, nurmiluiskia ja kävelykansia",

teoksessa Unelma paremmasta maailmasta, 139;

Jussi Jännes, As Oy Tornitaso, As Oy Säästökontu puistosuunnitelma, 1960-luvun loppu; Ibid. Asuntoosakeyhtiö Louhentie 5:n pihapuutarha, 1965-66.

35 Hurme, Suomalainen lähiö Tapiolasta

Pihlajamäkeen, 135
36 Hirvensalo, Modernin kaupungin luonto muutoksessa, 81.

37 Kirsi Saarikangas, "Rakennetun ympäristön muutos ja asumisen mullistus", teoksessa Suomalaisen arjen historia 4. Hyvinvoinnin Suomi, toim. Kai Häggman, Markku Kuisma, Pirjo Markkola et al. (Porvoo: Weilin + Göös, 2008), 31.

38 Meurman, Asemakaavaoppi, 360.

39 Mannerla-Magnusson et al., "Tapiola ja sen

jälkeinen aika", 144; Weckman et al., Keski-Vuosaari, 25.

40 Asuntosäästäjä-lehti 1963

41 Mannerla-Magnusson et al., "Tapiola ja sen

jälkeinen aika”, 144-145; Weckman et al., KeskiVuosaari, 13-16.

42 Luostarinen s.a., (Säästökeula), Säästöpoiju

ja Säästömasto, tonttialueen ja ympäristön

vihersuunnitelma, MFA.

43 Katri Luostarinen, As Oy Säästömaston kansipiha, ei vuotta, MFA.

44 Mannerla-Magnusson et al., "Tapiolan

jälkeinen aika", 148, 259; Katri Luostarinen, 1968, Erikoispiirustus.

45 Katri Luostarinen, Tyyppipiirustuksia, ei vuotta,

MFA.

46 Katri Luostarinen, Puutarha ja maisema (Helsinki WSOY, 1951), 109.

47 Luostarinen, Puutarha ja maisema, 59-61; AnnaLiisa Ahmavaara, Asumme lähellä luontoa (Helsinki: Otava, 1966), esipuhe.

48 Luostarinen, Puutarha ja maisema, 109.

49 Anne Helmreich, The English Garden and National Identity. The Competing Styles of Garden Design 1870-1914 (Cambridge: The Cambridge University Press, 2002), 135-154; John Dixon Hunt, A World of Gardens (London: Reaktion Books, 2012), 293. 50 Gert Groening, "The "Landscape Must Become the Law" - Or Should It?", Landscape Research 2007 , volume 32,5 , julkaistu myös https://

www.stadtbaukunst.org/cms/upload/texte_zur_ stadtbaukunst/, 15-16.
51 Thorbjörn Andersson, "From Paper to Park", teoksessa Representing Landscape Architecture, toim. Marc Treib (New York: Taylor \& Francis, 2008), 77

52 Dorothee Brantz \& Sonja Dümpelmann,

"Introduction", teoksessa Greening the city: urban landscapes in the twentieth century, toim. Dorothee Brantz \& Sonja Dümpelmann (Charlottesville: University of Virginia Press cop., 2011), 6; Ks. myös esim. Annikki Savonlahti, "Asumalähiön ihanuus ja kurjuus", Puutarha 10/1967, 412-413; O. Larsson, "Suuret kasviryhmät massaistutukset", Puutarha 10/1967, 408-409.

53 Hirvensalo, Modernin kaupungin luonto muutoksessa, 135-136.

54 Asko Salokorpi, "Arkkitehtuuri vuoden 1940 jälkeen", teoksessa ARS - Suomen taide, toim. Salme Sarajas-Korte (Espoo: Weilin + Göös, 1990), 55-61; Johanna Hankonen, Lähiöt ja tehokkuuden yhteiskunta. Suunnittelujärjestelmän läpimurto suomalaisten asuntoalueiden rakentumisessa 1960-luvulla (Espoo: Otatieto, 1994), 201, 467. 55 Pentti Murole, Ihmistä ei voi suunnitella - kiveä voi! Tarinoita suunnittelun maailmasta ja ihmisistä sen ympärillä (Helsinki: Arkkitehtuuritoimisto B\&M, 2012), 126.

56 Pentti Murole, "Ihmisen kulkemisen

suunnittelusta”, Arkkitehti 3-4/1967, 16-19; Kirmo

Mikkola, Metsäkaupungin synty: funktionalismin ja kaupunkisuunnittelun aatehistoria (Espoo: Teknillinen korkeakoulu, 1972), 204.

57 Hankonen, Lähiöt ja tehokkuuden yhteiskunta, 201.

58 Olavi Laisaari, Tehokas kaupunki (Turku: Turun kansallinen kirjakauppa, 1962), 32.

59 Reijo Jallinoja, "Itä-Pasilan asemakaavan suunnittelu ja toteutus", Arkkitehti 1/1974, 37-38. 60 Asemakaava 6688, selostus, 1971.

61 Pentti Murole, "Ihmisen kulkemisen suunnittelusta" Arkkitehti 3-4/1967, 16.

62 Unelma paremmasta maailmasta, 254 
63 Leena lisakkila, Maisema-arkkitehti ajan virrassa: maisema-arkkitehdin töitä ja ajatuksia neljän

vuosikymmenen ajalta (Helsinki: Puutarhaliitto, 2000), 39

64 lisakkila, Maisema-arkkitehti ajan virrassa, 34-35 39.

65 Asemakaava 6688, selostus, 1971; lisakkila,

Maisema-arkkitehti ajan virrassa, 40.

66 Asemakaava 6688, selostus, 1971; lisakkila,

Maisema-arkkitehti ajan virrassa, 39-41. Ks.

myös Leena lisakkila, Piha vihreäksi - neljä

suunnitteluesimerkkiä (Helsinki: Ympäristöministeriö,

1985)

67 Jallinoja, "Itä-Pasilan asemakaavan suunnittelu ja toteutus", 39; lisakkila, Maisema-arkkitehti ajan virrassa, 42.

68 Pentti Mustonen, Kaupungin sielua etsimässä.

Kertomus Helsingin kaupunkisuunnittelusta

Bertel Jungista nykyaikaan (Helsinki: Helsingin

kaupunkisuunnitteluvirasto, 2010), 367, 372.

69 Camilla Rosengren, "Viheralueet", teoksessa

Asuinaluesuunnittelu, toim. Riitta Jalkanen, Tapani

Kajaste, Timo Kauppinen, Pekka Pakkala ja Camilla

Rosengren (Helsinki: Rakennustieto, 1997), 156

70 lisakkila 1971, Tyyppipiha 1 ja 2.

71 lisakkila, Maisema-arkkitehti ajan virrassa, 59;

lisakkilan puhelinhaastattelu 2.8.2019.20

72 lisakkila, Puistojäsentelykaavio, 28.7.1971. MFA.

73 Leikkialueiden suunnittelu, Sisäasiainministeriö,

kaavoitusohjeita. Kaavoitus- ja rakennusosasto

2/1974.

74 Mustonen, Kaupungin sielua etsimässä, 367-368,

Jallinoja "Itä-Pasilan asemakaavan suunnittelu ja

toteutus", 40-41. 75 Susanna Kosonen, "Itä-Pasila

on salaa ihana kaupunginosa", Helsingin Sanomat 25.6 .2014

76 lisakkila, Maisema-arkkitehti ajan virrassa, 42

77 Ks. esim. Rachel Carson, Lois Darling \& Louis

Darling, Silent Spring (Boston (MA): Houghton Mifflin

Company, 1962).
TkT Ranja Hautamäki toimii maisema-arkkitehtuurin professorina Aalto-yliopistossa. Hän on tutkimuksessaan ja opetuksessaan suuntautunut historiallisiin maisemiin ja niiden kunnostukseen sekä viherrakenteeseen tiivistyvässä kaupungissa.

FT Julia Donner on taidehistorian tutkija, joka on työskennellyt tutkijatohtorina ja tuntiopettajana Aalto yliopistossa. Nykyisin hän toimii Ainola - Aino ja Jean Sibeliuksen koti -museon johtajana.

Donner on tutkimuksessaan perehtynyt suomalaisen puutarhan ja maiseman historiaan. 